\title{
Stability of Common Biochemical Analytes in Serum when Subjected to Changes in Storage Conditions and Temperature
}

\author{
P Kughapriya $^{1}$, JA Elanchezhian ${ }^{2}$
}

\begin{abstract}
Aim: The aim of the study was to assess the effect of storage time and temperature on the test results of 8 common biochemical analytes in serum.

Materials and methods: Five $\mathrm{mL}$ of blood was collected from apparently healthy 80 volunteers in a clotactivatortube without anticoagulant. Serum was separatedafterallowing the sampletoclotfor 30 minutesatroom temperature.Separated serum wasmadeinto fouraliquots. Thefirst partanalyzed within two hours act as a baseline value, while the other three aliquots were stored at room temperature for four hours, at $2-8^{\circ} \mathrm{C}$ for four hours and at $2-8^{\circ} \mathrm{C}$ for 24 hours, respectively.

Results: Baseline serum values of common biochemical analytes analyzed within two hours of sample collection on comparison with the same sample stored at room temperature for four hours showed a significant change in the values of glucose, urea, creatinine, total bilirubin, albumin, and total protein. Also the values of glucose, urea and albumin were significantly changed on comparing the baseline sample with the sample that is stored for four hours at $2-8^{\circ} \mathrm{C}$. Finally we compared the baseline values with the sample stored at $2-8^{\circ} \mathrm{C}$ for 24 hours and found a significant change among the values of glucose, total bilirubin, and albumin. Other analytes were found to be stable.
\end{abstract}

Conclusion: According to our study, storage of common biochemical analytes in serum like glucose, urea, bilirubin, and albumin is not advisable. Serum creatinine and total protein were stable on refrigeration. Total cholesterol and triglycerides were found to be stable.

Clinical significance: In the context of patient centered approach to the delivery of healthcare services, clinical laboratories play a vital role. Despite the improvements made in the laboratory, errors still occur due to inadequate insight about the importance of sample collection and storage procedures. Errors in sample handling affects test report which diminishes the confidence in healthcare services and damages an institution's reputation. Significant interdepartmental cooperation is very essential for identification and proper management of preanalytical errors which inturn will help to make valuable medical decision and effective patient care.

Keywords: Accuracy, Aliquot, Analytes, Preanalytical, Precision.

Indian Journal of Medical Biochemistry (2019): 10.5005/jp-journals-10054-0080

\section{A IM}

To evaluate the stability of eight common biochemical analytes in serum samples due to time delay and changes in temperature.

\section{Objectives}

- To evaluate the stability of biochemical analytes in serum when stored for different time duration.

- Biochemical analytes were assayed in serum on subjecting them to different temperature conditions.

\section{INTRODUCTION}

Physicians and clinicians use laboratory test to aid in the diagnosis, monitoring, prognosis and follow up of diseases as we live in an era of evidence-based medicine. Hence precision and accuracy of a test result are important. Several steps in the procedure include patient preparation, sample collection, processing of samples, analysis, reporting, and interpretation of test results. The sources of errors that affect the accuracy of test results are classified into preanalytical, analytical and postanalytical. ${ }^{1,2}$ Preanalytical errors are the most common errors in the laboratories. Many preanalytical variables like specimen storage time, specimen storing temperature can be monitored and controlled thereby reducing the magnitude of the errors and improving the accuracy of the test result. ${ }^{3,4}$

In our study, we analyzed eight common biochemical parameters in serum in an attempt to detect quantitative variations when stored for different period and temperature.
${ }^{1}$ Assistant Professor, ${ }^{2}$ Associate Professor

${ }^{1}$ Department of Biochemistry, Government Mohan Kumaramangalam Medical College Hospital, Salem, Tamil Nadu, India

${ }^{2}$ Department of General Medicine, Government Mohan Kumaramangalam Medical College Hospital, Salem, Tamil Nadu, India

Corresponding Author: P Kughapriya, Assistant Professor, Department of Biochemistry, Government Mohan Kumaramangalam Medical College Hospital, Salem, Tamil Nadu, India, e-mail: kughapriya74@gmail. com

How to cite this article: Kughapriya P, Elanchezhian JA. Stability of Common Biochemical Analytes in Serum when Subjected to Changes in Storage Conditions and Temperature. Indian J Med Biochem 2019;23(1):178-181.

Source of support: Nil

Conflict of interest: None

\section{Materials AND METHODS}

A cross-sectional study was undertaken in the Department of Biochemistry, Government Mohan Kumaramangalam Medical College, Salem, Tamil Nadu, India. Eighty healthy persons visiting master health checkup OPD in our hospital were taken up for the study after getting proper informed consent. The study was approved by the ethical committee of our college.

\section{Inclusion Criteria}

Healthy volunteers of age group 25-60 years were taken up for the study.

(C) The Author(s). 2019 Open Access This article is distributed under the terms of the Creative Commons Attribution 4.0International License (https://creativecommons. org/licenses/by-nc/4.0/), which permits unrestricted use, distribution, and non-commercial reproduction in any medium, provided you give appropriate credit to the original author(s) and the source, provide a link to the Creative Commons license, and indicate if changes were made. The Creative Commons Public Domain Dedication waiver (http://creativecommons.org/publicdomain/zero/1.0/) applies to the data made available in this article, unless otherwise stated. 


\section{Exclusion Criteria}

Critically ill patients, children, and antenatal mothers are excluded from the study.

\section{Specimen Collection and Processing}

Five $\mathrm{mL}$ of venous blood was collected from 80 volunteers. Among them, there were 37 females and 43 males. Blood was collected in sterile clot activator tubes. The samples were allowed to clot for 30 minutes at room temperature. ${ }^{5}$ Samples were centrifuged at $2000 \mathrm{rpm}$ for 10 minutes. Samples with visible hemolysis were excluded from the study. Serum was separated as early as possible within two hours from sample collection ${ }^{6}$ and made into four aliquots and analyzed differently using EM 200 autoanalyzer.

- I aliquot: The separated serum is analyzed within two hours at room temperature $\left(20-25^{\circ} \mathrm{C}\right)$ and they act as a baseline value.

- Il aliquot: Serum is kept at room temperature $\left(20-25^{\circ} \mathrm{C}\right)$ and analyzed after four hours.

- III aliquot:Serum is stored in a refrigerator at $2-8^{\circ} \mathrm{C}$ and analyzed after four hours.

- IV aliquot: Serum is stored in a refrigerator at $2-8^{\circ} \mathrm{C}$ analyzed after 24 hours.

\section{Analysis}

Serum was analyzed for eight common biochemical parameters like glucose, urea, creatinine, triglycerides, cholesterol, total protein, albumin and total bilirubin from all the four aliquots. The parameters were assayed using XL system packs from Erba diagnostics (Trans Asia Biomedicals Ltd Baddi, HP in collaboration with ERBA Diagnostics Mannheim GmbH, Mallaustr, Mannheim/ Germany). Quality control values for the analytes that we studied were within \pm 2 SD (standard deviation) of their respective target means.

\section{Glucose Measurement: (GOD-POD Method)}

The enzyme glucose oxidase catalyzes the oxidation of glucose to gluconic acid and hydrogen peroxide. The enzyme peroxidase catalyzes the coupling of aminoantipyrine with phenol to yield a colored quinonimine complex and its absorbance was determined at the wavelength of $500 \mathrm{~nm}$.

\section{Urea Measurement: (Urease-GLDH Method)}

Urea is hydrolyzed by urease to ammonia and $\mathrm{CO}_{2}$. In the presence of (GLDH) glutamate dehydrogenase, ammonia combines with-ketoglutarate to form L-glutamate and its absorbance was determined at the wavelength of $340 \mathrm{~nm}$.

\section{Creatinine Measurement: (Modified Jaffe's)}

Creatinine reacts with alkaline picrate to yield an orange-red colored complex whose absorbance was measured at $510 \mathrm{~nm}$.

\section{Triglyceride Measurement: (GPO Method)}

Triglycerides are hydrolyzed by lipase to glycerol and fatty acid. Glycerol is phosphorylated by ATP with glycerol kinase to produce glycerol3-phosphate. Addition of the enzyme glycerol-3-phosphate oxidase results in the formation of dihydroxyacetone phosphate and $\mathrm{H}_{2} \mathrm{O}_{2}$. $\mathrm{H}_{2} \mathrm{O}_{2}$ reacts with $\mathrm{N}$-ethy-1-Nsulfohydroxypropyl-m-toluidine and 4aminoantipyrine catalyzed by peroxidase to form a colored compound and its absorbance was determined at the wavelength of $546 \mathrm{~nm}$.

\section{Albumin Measurement: (BCG Method)}

Serum albumin reacts with bromocresol green (BCG) to form a colored compound and its absorbance was measured at the wavelength of $630 \mathrm{~nm}$.

\section{Total Protein Measurement: (Biuret method)}

The coordination complex formed between the cupric ions and the nitrogen of the peptide bond gives a purple color product whose absorbance was measured at $550 \mathrm{~nm}$.

\section{Total Cholesterol Measurement: (Cholesterol Oxidase Method)}

Cholesterol ester is converted to cholesterol and fatty acid by the enzyme cholesterol esterase. Addition of the enzyme cholesterol oxidase results in the formation of 4-cholesten-3-one and $\mathrm{H}_{2} \mathrm{O}_{2}$. A colored compound is obtained on addition the enzyme peroxidase, phenol, and 4-aminoantipyrine whose absorbance was determined at the wavelength of $500 \mathrm{~nm}$.

\section{Total Bilirubin Measurement: (Walter and Gerarde Method)}

Bilirubin is coupled with diazotized sulfanilic acid in the presence of ethylene glycol and dimethyl sulfoxide to produce a coloured dye whose absorbance was measured at $546 \mathrm{~nm}$.

\section{Statistical Analysis}

A $p$ value was derived by applying student T-test using SPSS version 24. For $p<0.05$ is considered as statistically significant.

\section{Results}

In comparison of the means of the serum analytes analysed within two hours at room temperature $\left(20-25^{\circ} \mathrm{C}\right)$ to that of the sample stored for four hours at room temperature showed a significant change as per Table 1 in the values of glucose ( $p$ value $<0.001$ ), urea

Table 1: Changes in the mean value of serum analytes when stored for four hours at room temperature

\begin{tabular}{llllll|}
\hline S.no & Analytes & Sample size & Wthin 2 hours Mean \pm SD & 4 hours at RT Mean \pm SD & $p$ value \\
\hline 1 & Glucose $\mathrm{mg} / \mathrm{dL}$ & 80 & $121.65 \pm 60.13$ & $111.48 \pm 56.72$ & $<0.001^{\mathrm{a}}$ \\
2 & Urea $\mathrm{mg} / \mathrm{dL}$ & 80 & $26.93 \pm 10.24$ & $25.15 \pm 10.07$ & $<0.001^{\mathrm{b}}$ \\
3 & Creatinine $\mathrm{mg} / \mathrm{dL}$ & 80 & $1.15 \pm 0.55$ & $1.11 \pm 0.48$ & $0.005^{\mathrm{c}}$ \\
4 & Cholesterol $\mathrm{mg} / \mathrm{dL}$ & 80 & $191.61 \pm 44.72$ & $191.10 \pm 43.32$ & 0.941 \\
5 & Triglycerides $\mathrm{mg} / \mathrm{dL}$ & 80 & $161.74 \pm 90.09$ & $0.51 .62 \pm 89.59$ & 0.993 \\
6 & Total bilirubin $\mathrm{mg} / \mathrm{dL}$ & 80 & $0.55 \pm 0.44$ & $3.61 \pm 0.18$ & $<0.001^{\mathrm{d}}$ \\
7 & T Albumin $\mathrm{g} / \mathrm{dL}$ & 80 & $3.58 \pm 0.19$ & $7.09 \pm 0.53$ & $0.002^{\mathrm{e}}$ \\
8 & T Protein $\mathrm{g} / \mathrm{dL}$ & 80 & $7.26 \pm 0.52$ & & $0.024^{\mathrm{f}}$ \\
\hline
\end{tabular}

Mean with superscript $a, b, c, d, e, f$ show significant change. $p<0.05$ statistically significant 
( $p$ value $<0.001)$, creatinine $(p=0.005)$, total bilirubin $(p$ value $<0.001)$, albumin $(p=0.002)$ and total protein $(p=0.024)$. In the analysis of total cholesterol and triglycerides, there was no significant change.

In Table 2, the means of test values of sample analytes that are analyzed within two hours were compared with the means of the analytes analyzed within four hours after storing at $2-8^{\circ} \mathrm{C}$. Table 2 showed significant changes in the $p$ values of glucose ( $p$ value $<0.001)$, urea ( $p$ value $<0.001)$ and albumin $(p=0.002)$. Other analytes showed no significant change.

Comparison of the means of sample analyzed within two hours and the samples stored at 2 to $8^{\circ} \mathrm{C}$ for 24 hours was shown in Table 3. A significant change of $p$ value $<0.001$ was observed in the values of glucose, total bilirubin, and albumin. Other analytes were not significantly affected when stored at $2-8^{\circ} \mathrm{C}$ as shown in Table 3.

\section{Discussion}

Small changes in specimen processing or handling can have dramatic effects in analytical reliability and reproducibility of test results. Serum is the liquid portion of the blood devoid of cellular elements and clotting factors. Blood samples require 30-60 minutes to clot at room temperature. When the serum samples were allowed less than 30 minutes then, retained cells and contamination can occur. When the serum samples were allowed more than 60 minutes, cellular components may be released due to cell lysis. ${ }^{7}$ Ideal time of serum separation from the sample for most of the common biochemical analytes is within two hours as per the recommendations of Clinical and Laboratory Standards Institute. ${ }^{8}$ The time of storage of serum after separation and the temperature at which they are stored affect the test results. Improper methods may be followed in the laboratory due to the increase in sample load. Our study aims at identifying the stability of some common analytes when subjected to different storage conditions.

In the study conducted by Selvakumar et al., time delay in the analysis, the effect of ambient temperature and the effect of hemolysis are studied for common analytes like glucose, urea, creatinine, electrolytes and Alkaline phosphatase. Their results showed a significant change in serum glucose and Alkaline phosphatase levels after four hours and 24 hours at room temperature. ${ }^{9}$ In the study conducted by Cuhadar et al. aims at determining the stability of analytes in serum gel tubes and plain tubes when subjected to varying storage time and temperature. The samples were stored at 4 or $24^{\circ} \mathrm{C}$ for $6,12,18,24,30,36,48$ and 72 hours and 1 week. In their study glucose, total bilirubin, urea nitrogen and uric acid stored at $4^{\circ} \mathrm{C}$ in gel tubes showed more stability. ${ }^{10}$

In our study, delay in the analysis showed changes in serum glucose which could be attributed to its utilization by glycolysis. Glucose is required for cellular metabolism and the rate at which glucose is depleted is dependent on temperature and time. At higher temperatures, there is a higher metabolic rate and glucose is depleted quickly, whereas at lower temperatures it is depleted more slowly. ${ }^{11,12}$ No preservatives were added in the glucose sample in our study. Sodium fluoride is preferred as a preservative added to blood samples collected for glucose estimation to prevent glycolysis. ${ }^{13}$

We observed a significant change in urea levels as per Table 2 in which the mean urea concentration stored for four hours at $2-8^{\circ} \mathrm{C}(25.37 \pm 9.80 \mathrm{mg} / \mathrm{dL})$ was compared to urea analyzed within two hours at room temperature $(26.93 \pm 10.24$ $\mathrm{mg} / \mathrm{dL}$ ). This was in contrast to some study where urea sample was found to be stable for 15 days when stored at $0-4^{\circ} \mathrm{C} .{ }^{14}$ The decrease in urea concentration may not be considered as clinically significant though there is statistical significance. This could be attributed to

Table 2: Changes in the mean value of serum analytes when stored at at $2-8^{\circ} \mathrm{C}$ for 4 hours

\begin{tabular}{|c|c|c|c|c|c|}
\hline S.no & Analytes & Sample size & Wthin 2 hours Mean $\pm S D$ & 4 hours at $2-8^{\circ} \mathrm{C}$ Mean $\pm S D$ & $p$ value \\
\hline 1 & Glucose $\mathrm{mg} / \mathrm{dL}$ & 80 & $121.65 \pm 60.13$ & $116.4 \pm 57.66$ & $<0.001^{\mathrm{a}}$ \\
\hline 2 & Urea mg/dL & 80 & $26.93 \pm 10.24$ & $25.37 \pm 9.80$ & $<0.001^{\mathrm{b}}$ \\
\hline 3 & Creatinine mg/dL & 80 & $1.15 \pm 0.55$ & $1.13 \pm 0.48$ & 0.082 \\
\hline 4 & Cholesterol mg/dL & 80 & $191.61 \pm 44.72$ & $192.81 \pm 43.79$ & 0.268 \\
\hline 5 & Triglycerides mg/dL & 80 & $161.74 \pm 90.09$ & $160.80 \pm 87.78$ & 0.494 \\
\hline 6 & Total bilirubin $\mathrm{mg} / \mathrm{dL}$ & 80 & $0.55 \pm 0.44$ & $0.55 \pm 0.44$ & 0.987 \\
\hline 7 & T Albumin g/dL & 80 & $3.58 \pm 0.19$ & $3.63 \pm 0.17$ & $0.002^{c}$ \\
\hline 8 & T Protein $\mathrm{g} / \mathrm{dL}$ & 80 & $7.26 \pm 0.52$ & $7.30 \pm 0.63$ & 0.583 \\
\hline
\end{tabular}

Table 3: Changes in the mean value of serum analytes when stored at $2-8^{\circ} \mathrm{C}$ for 24 hours

\begin{tabular}{llllll}
\hline S. no. & Analytes & Sample size & Wthin 2 hours Mean \pm SD & 4 hours at 2- $8^{\circ}$ CMean $\pm S D$ & $p$ value \\
\hline 1 & Glucose $\mathrm{mg} / \mathrm{dL}$ & 80 & $121.65 \pm 60.13$ & $111.74 \pm 59.03$ & $<0.001^{\mathrm{a}}$ \\
2 & Urea $\mathrm{mg} / \mathrm{dL}$ & 80 & $26.93 \pm 10.24$ & $26.93 \pm 10.65$ & 1.00 \\
3 & Creatinine $\mathrm{mg} / \mathrm{dL}$ & 80 & $1.15 \pm 0.55$ & $1.13 \pm 0.48$ & 0.310 \\
4 & Cholesterol $\mathrm{mg} / \mathrm{dL}$ & 80 & $191.61 \pm 44.72$ & $191.54 \pm 44.11$ & 0.950 \\
5 & Triglycerides $\mathrm{mg} / \mathrm{dL}$ & 80 & $161.74 \pm 90.09$ & $160.50 \pm 90.19$ & 0.411 \\
6 & Total bilirubin $\mathrm{mg} / \mathrm{dL}$ & 80 & $0.55 \pm 0.44$ & $0.51 \pm 0.44$ & $<0.001^{\mathrm{b}}$ \\
7 & T Albumin $\mathrm{g} / \mathrm{dL}$ & 80 & $3.58 \pm 0.19$ & $3.66 \pm 0.17$ & $<0.001^{\mathrm{c}}$ \\
8 & T Protein $\mathrm{g} / \mathrm{dL}$ & 80 & $7.26 \pm 0.52$ & $7.26 \pm 0.79$ & 0.966 \\
\hline a,b,c show significant change & & & &
\end{tabular}


the smaller sample size. As per Table 3, we did not observe any statistically significant change.

We noticed stability of serum creatinine when the samples were stored at $2-8^{\circ} \mathrm{C}$. Instability was noticed in the sample kept at room temperature. As per the study conducted by Shepherd et al. instability among serum creatinine values were reported within 24 hours using Jaffe's method for estimation which was attributed to some interference like ketones and pyruvates. ${ }^{15}$

In accordance with the study conducted by Kachhawa et al. and Comstock et al., serum cholesterol and triglyceride concentrations were found to be stable. ${ }^{16,17}$ In our study, total bilirubin showed significant variation when stored at room temperature for four hours and 24 hours at $2-8^{\circ} \mathrm{C}$. We placed the samples in artificial light at room temperature and in the refrigerator without any protection. Total bilirubin was found to be stable for 24 hours in other studies. ${ }^{18}$ Stability was found to be better in gel tubes stored at $4^{\circ} \mathrm{C}$ for total bilirubin in the study conducted by Serap. ${ }^{9}$

Total protein in the lyophilized sample was found to be stable in the study conducted by Lawson et al., ${ }^{19}$ but in our study, statistical instability was observed when total protein was stored at room temperature, other samples stored at $2-8^{\circ} \mathrm{C}$ were stable. We also observed changes in serum albumin in all the stored samples. The stability of proteins in serum samples are temperature dependent. Steps should be taken to prevent delay in sample processing to minimize the degradation of proteins. ${ }^{20,21}$ This study helped us to identify the useful length of storage time for common serum analytes.

\section{CONCLUSION}

In our study, we observed a significant change among common biochemical analytes in serum like glucose, urea, bilirubin, and albumin upon storage over a different period and temperature. So it is advisable to assay these samples within 2 hours after receiving the samples. Serum creatinine and total protein showed no significant changes in refrigerated samples. Total cholesterol and triglycerides were found to be stable even after some time delay. This study helped us to identify sensitive analytes that significantly vary when not stored properly. The results from our study helped us to determine those analytes that produce valid results despite exposure to variable storage conditions. This knowledge will help us to improve the precision and accuracy of current diagnostic strategies.

\section{Study Limitation}

- Sample size was small.

- Run to run variation was not studied.

- Analysis was not done in duplicates to ensure the reliability of results.

\section{References}

1. Kaplan LA. Determination and Application of Desirable Analytical Performance Goals: the ISO/TC 212 approach. Scandivian J. Clin. Lab Investi. 1999;59:479-482.

2. Plebani M, Carraro P. Mistakes in a stat laboratory: types and frequency. Clin Chem 1997;43:1348-1351.

3. Carraro P, Plebani M. Errors in a stat laboratory: types and frequencies 10 years later. Clin Chem 2007;53:1338-1342.

4. Kouri T, Siloaho M, Pohjavaara S, et al., Pre-analytical factors and measurement uncertainty, Scand J Clin Lab Invest 2005;65:463-476.

5. Arzoumanian L. BD Technical Services News Bulletin 2003;2(2).

6. Burtis CA, Ashood ER, Burns DE. Tietz Textbook of clinical chemistry and molecular diagnostics. Fifth edition. Elsevier 2012;145-161.

7. Timms JF, Arslan-Low E, Gentry-Maharaj A, et al. Clin Chem. PubMed. 2007;53(4):645-656.

8. $\mathrm{CLSI}$ document $\mathrm{H} 18-\mathrm{A} 3$. Procedures for the Handling and Processing of Blood Specimens; Approved Guideline. 3rd edn. 2004.

9. Selvakumar C, Madhubala V. Effect of sample storage and time delay (delayed processing) on analysis of common clinical biochemical parameters. International Journal of Clinical Biochemistry and Research, July-September 2017;4(3):295-298.

10. Cuhadar S, Atay A, Koseoglu M, et al. Stability studies of common biochemical analytes in serum separator tubes with or without gel barrier subjected to various storage conditions. Biochemia Medica 2012;22(2):202214.

11. Bruns DE, William C. Knowler. Stabilization of Glucose in Blood Samples: Why It Matters. Clin Chem 2009 Mar;55(5):850-852.

12. Stahl M, Jorgensen LGM, Hyltoft Petersen $P$, et al. Optimization of preanalytical conditions and analysis of plasma glucose. Impact of the new $\mathrm{WHO}$ and ADA recommendations on diagnosis of diabetes mellitus. Scand J Clin Lab Invest 2001;61:169-180.

13. Chan AYW,Swaminathan R, Cockram CS. Effectiveness of sodium fluoride as a preservative of glucose in blood. Clin Chem 1989;35:315317.

14. Pahwa M, Menaka K, Minakshi, et al. Effect of storage time and temperature on serum clinical biochemistry analytes. BCAIJ, 2015;9(4):150-156.

15. Shepherd J, Warner MH, Kilpatrick ES. Stability of creatinine with delayed separation of whole blood and implications for eGFR. Ann Clin Biochem 2007;44:384-387.

16. Kachhawa K, Kachhawa P, Varma M, et al. Study of the Stability of Various Biochemical Analytes in Samples Stored at Different Predefined Storage Conditions at an Accredited Laboratory of India. J Lab Physicians 2017 Jan-Mar; 9(1):11-15.

17. Comstock GW, Burke AE, Norkus EP, et al. Effects of repeated freezethaw cycles on concentrations of cholesterol, micronutrients, and hormones in human plasma and serum. ClinChem 2001; 47:139-142.

18. Sofronescu AG, Loebs T, Zhu Y. Effects of temperature and light on the stability of bilirubin in plasma samples. Clin Chim Acta. 2012 Feb;18;413(3-4):463-466.

19. Lawson NS, Haven GT, Moore TD. Long-term stability of enzymes, total protein, and inorganic analytes in lyophilized quality control serum. Am J Clin Pathol. 1977 Jul; 68(1 Suppl):117-129.

20. Mitchell BL, Yasui Y, Li Cl, et al. Cancer Inf. PubMed. 2005;1(1):98-104.

21. Rai AJ, Gelfand CA, Haywood B, et al. Proteomics. PubMed. 2005;5(13):3262-3277. 